\title{
A Comparative Study of AZF Deletions and TSPY Gene Variation in Czech and Indian Infertile Men
}

\author{
Arvind Rup Singh*, Radek Vrtel, Radek Vodicka, Ishraq Dhaifalah, \\ David Konvalinka and Jiri Santavy \\ Department of Medical Genetics \& Fetal Medicine, University Hospital, Palacky University, \\ I.P. Pavlova 6, Olomouc 775 20, Czech Republic \\ *Fax: 00420-585-414-906, *E-mail: dravi@carolina.rr.com
}

KEYWORDS AZF; microdeletions; TSPY; Y chromosome; male infertility

\begin{abstract}
The human Y chromosome harbours genes that are essential for spermatogenesis. Most of these genes lie in the male-specific region (MSY) of Y chromosome. Microdeletions of AZF within the MSY have been reported in infertile men. Widely different frequencies of such deletions $(0-55 \%)$ have been reported from different populations. TSPY is another gene located in the MSY region that plays a significant role in spermatogenesis. It is a multi-copy gene but the role its gene copy numbers play in infertility is not yet evaluated. The present study was undertaken on infertile men from Czech Republic and India to ascertain the relative and comparative role of AZF deletions and of TSPY copy numbers.
\end{abstract}

\section{INTRODUCTION}

Male infertility can be caused by a variety of factors that include cryptorchidism, ductal obstruction, hormonal dysfunction, retrograde ejaculation, systemic diseases, testicular cancer, testicular trauma, varicocele, etc. Apart from these in $~ 30 \%$ of male infertility cases, that are referred to as idiopathic, genetic abnormality at molecular level is suspected (Huynh et al. 2002). Most of the genes associated with male infertility lie in the male-specific region (MSY) of Y chromosome (Singh et al. 2005a). Micro-deletions of AZF especially of $\mathrm{AZFa}, \mathrm{AZFb}$, and $\mathrm{AZFc}$ regions, within the MSY have been reported in infertile men. Widely different frequencies of such deletions, ranging from $0 \%$ to $55 \%$, have been reported (Foresta et al. 1998; Kihaile et al. 2005). This large inter-laboratory variation in the frequency of AZF deletions is probably due to the type of patients selected for Y chromosome analysis (McElreavey and Krausz 1999).

Another Y chromosome gene, TSPY (GDB: 120471), is a multicopy gene and most of its copies are located on the MSY region. This gene family has 20-40 gene copies that vary from individual to individual (Dechend et al. 2000). Its prototype

Corresponding author: Dr. Arvind Rup Singh Department of Medical Genetics \& Fetal Medicine, University Hospital, Palacky University, I.P. Pavlova 6, Olomouc 775 20, Czech Republic

Fax: 00420-585-414-906

E-mail:dravi@carolina.rr.com coding sequence is $924 \mathrm{bp}$ and a sequence divergence of $10 \%$ has been reported in human TSPY sequences (Arnemann et al. 1991; Manz et al. 1993). The function of TSPY sequences is to integrate TSPY protein into spermatogenesis (Vogel et al. 1997) and it is involved in the proliferation of germ cells (Schnieders et al. 1996). Conard et al. (1996) proposed that RBM and TSPY genes might have originated form a common organization on an ancient Y chromosome. As RBM is an AZF candidate gene, the possible role of TSPY in spermatogenesis is further strengthened. However, whether the gene copy numbers of TSPY play a role in male infertility is yet to be evaluated.

It is important to ascertain the AZF deletions and the role of TSPY copy numbers when ICSI procedures have to be followed for diagnosis, prediction of prognosis and genetic counseling of the infertile couple.

The present study was undertaken on infertile men from Czech Republic and from India (Punjab; North West India), following same procedures, to ascertain the role of AZF deletions and TSPY copy numbers in these two geographically and ethnically different populations.

\section{MATERIALS AND METHODS}

The presence or absence of micro-deletions of AZF involving the AZFa, AZFb and AZFc regions were evaluated in 219 individuals (Table 1) in the present study. The TSPY gene analysis 
Table 1: Details about the patients studied

\begin{tabular}{lc}
\hline Patient group & Number of patients \\
\hline Czech patients & \\
$\quad$ Azoospermia & 32 \\
Oligospermia & \\
$<5$ million sperms $/ \mathrm{ml}$ & 48 \\
$>5$ million sperms $/ \mathrm{ml}$ & 19 \\
$\quad$ Testicular feminization & 2 \\
$\quad$ syndrome $(46, \mathrm{XY})$ & \\
$\quad$ Klinefelter syndrome mosaic & 2 \\
$\quad$ (47,XXY/46,XY) & 47 \\
$\quad$ Controls & \\
Indian patients & 39 \\
$\quad$ Azoospermia & 30 \\
$\quad$ Controls & 219 \\
\hline Total &
\end{tabular}

was undertaken on 84 cases. These included 24 azoospermics and 40 controls from Czech Republic and 20 azoospermics from India (Punjab, North West India). All Czech patients were analyzed at Department of Medical Genetics and Fetal Medicine, University Hospital, Palacky University, Olomouc, while Indian patients were analyzed at Centre for Genetic Disorders, Guru Nanak Dev University, Amritsar, India. In all the infertile cases investigated, the endocrine disorders, trauma, chronic diseases, cryptorchidism were ruled out and karyotyping had been undertaken.

DNA was isolated from peripheral blood, using Miller's method (Miller et al. 1998). Simplex PCR was used for detecting micro-deletions of the $\mathrm{AZF}$ region on $\mathrm{Y}$ chromosome in order to prevent misinterpretation of accidental false positives. Seven informative markers of sequence-tagged-sites (STS) were used (Table 2).

The PCR cocktail for SY87, SY134, SY147, and SY158 STS marker consisted of $16.15 \mu$ l deionized water; $2.50 \mu 110 \mathrm{x}$ concentrated PCR buffer; 1.25 $\mu \mathrm{l}$ of $50 \mathrm{mM} \mathrm{MgCl}_{2} ; 0.50 \mu \mathrm{l} 100 \mathrm{mM}$ dNTPs; 1.25 $\mu 1$ Forward Primer; $1.25 \mu$ l Backward Primer; 0.10 $\mu \mathrm{l}$ Taq polymerase (concentration $5 \mathrm{U} / \mu \mathrm{l}) ; 2.00 \mu \mathrm{l}$ DNA $(100 \mathrm{ng} / \mu \mathrm{l})$. The final reaction volume used was $25 \mu 1$. The PCR cocktail for SY84, SY143, and SY255 STS markers consisted of $13.65 \mu 1$ deionized water and $2.50 \mu \mathrm{l}$ DMSO. All other constituents were the same as detailed for other STS markers. The PCR program used for all the above mentioned markers was the same. It consisted of initial denaturation $\left(94^{\circ} \mathrm{C}\right)$, denaturation $\left(94^{\circ} \mathrm{C}\right)$, annealing $\left(56^{\circ} \mathrm{C}\right)$ and elongation $\left(72^{\circ} \mathrm{C}\right)$ cycles each of 1 minute. The total number of cycles was 35 .

Refined Quantitative Fluorescent PCR (Vodicka et al. 2004) was used to analyze the copy numbers of TSPY gene and for this multiplex PCR was utilized. The single copy genes AMELX and AMELY (Table 2) acted as control genes to determine relative amplifications of TSPY. The PCR cocktail and conditions for multiplex PCR were as described by Singh (2005).

To ascertain the number of amplification cycles that give best results for the evaluation of various indices with respect to TSPY copy numbers, and AMELX and AMELY indices, each

Table 2: Details of the loci/STS markers studied and primers used

\begin{tabular}{|c|c|c|}
\hline Locus/STS markers & Cytogenetic localization & $\begin{array}{l}\text { Sequence } \\
\text { (1: forward; } 2: \text { reverse })\end{array}$ \\
\hline AMEL X/Y & $\begin{array}{l}\text { Xp22.31-p22.1 } \\
\text { Yp11.2 }\end{array}$ & $\begin{array}{l}5 ' \text {-ctgatggttggcctcaagcct- }{ }^{\prime}, \\
5 \text {-atgaggaaaccagggttcca- } 3\end{array}$ \\
\hline TSPY & Yp11.1 - q11.1 & $\begin{array}{l}5, \text {-cggggaagtgtaagtgaccgatggg- } \\
5,\end{array}$ \\
\hline SY84 & Yq11-q11 & $\begin{array}{l}5,- \text { agaagggtctgaaagcaggt- } 3 \\
5, \text {-gcctactacctggaggcttc }-3\end{array}$ \\
\hline SY87 & Yq11-q11 & $\begin{array}{l}5,- \text { tctgttgcttgaaaagaggg- } 3, \\
5, \text {-actgcaggaagaatcagctg- } 3,\end{array}$ \\
\hline SY134 & Yq11-q11 & $\begin{array}{l}5,- \text { gtctgcctcaccataaaacg- } 3, \\
5, \text {-accactgccaaactttcaa- } 3,\end{array}$ \\
\hline SY143 & Yq11-q11 & $\begin{array}{l}5,- \text { gcaggatgagaagcaggtag- } 3, \\
5,- \text { ccgtgtgctggagactaatc- } 3\end{array}$ \\
\hline SY147 & Yq11-q11 & $\begin{array}{l}5, \text {-ttctcgttgatgatcctag- } 3, \\
5,- \text { ttaatatgagaatgagaacagatgt- } 3\end{array}$ \\
\hline SY255 & & $\begin{array}{l}5,- \text {-gttacaggattcggcgtgat- } 3 \\
5, \text {-ctcgtcatgtgcagccac- } 3\end{array}$ \\
\hline SY 158 & Yq11-q11 & $\begin{array}{l}5,- \text { ctcagaagtcctcctaatagttcc- } 3 \text {, } \\
5,- \text { acagtggtttgtagcgggta- } 3\end{array}$ \\
\hline
\end{tabular}


of the samples was simultaneously amplified for four different amplification cycles, i.e., 22, 24, 26 and 28 .

Agarose gel electrophoresis was used to detect various deletions. The PCR products were separated on $1.5 \%$ agarose gel $(80 \mathrm{~V}$; $45-60 \mathrm{~min})$ and stained with ethidium bromide. The analysis of TSPY gene copy numbers was undertaken with ABI PRISM 310 capillary electrophoresis. The digital data of TSPY was evaluated with ABI Prism 310 Data Collection software.

\section{RESULTS}

\section{AZF Micro-deletions}

The specificity and efficacy of PCR conditions with respect to all seven STS markers were confirmed by observing the amplification of samples from fertile men. AZF micro-deletions were detected among six azoospermic men ( 3 each from Czech Republic and India) only, while none was seen in any other category of infertile men or amongst the 47 Czech and 30 Indian controls.

Only one deletion for the AZFa region was detected amongst the azoospermic males from Czech Republic (case no. CZ-78/03) and no case with deletions involving only the $\mathrm{AZFb}$ region was seen. Two azoospermic cases each, from Czech Republic and India (case nos. CZ-304/04, CZ-333/04 and IN-5, IN-29, respectively) showed deletions involving only the $\mathrm{AZFc}$ region. Among these, case numbers CZ 304/04 and IN-29 showed deletions with all three STS markers, i.e., sY147, sY158 and sY255. One case (CZ-333/04), showed deletions for the markers sY147 and sY255 only (Fig. 1) and another case (IN-9), showed deletions with all seven STS markers indicating the deletion of all regions of AZF, viz., $\mathrm{AZFa}, \mathrm{AZFb}$ and $\mathrm{AZFc}$.

The experiments for all those cases that

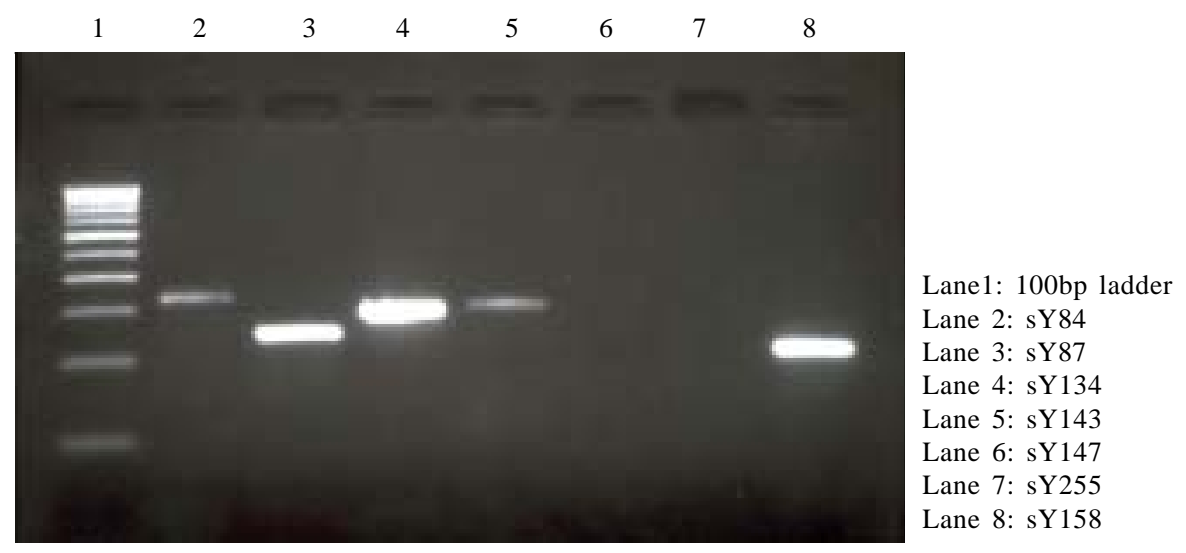

Fig. 1. AZFc deletion in CZ-333/04. Non-amplification of sY147 and sY255
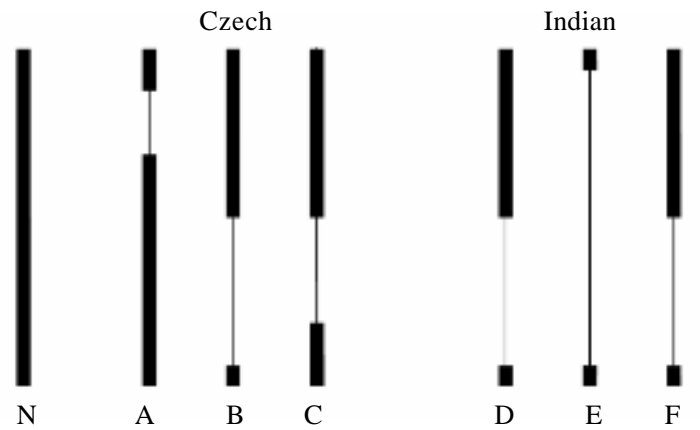
$\mathrm{N}$ : Normal
A: $\mathrm{CZ}-78 / 03(\mathrm{AZFa})$
B: CZ-304/04 (AZFc)
C: $\mathrm{CZ}-333 / 04$ (AZFc partial)
D: IN-5 (AZFc)
E: IN-9 (AZFa,b,c)
F: IN-29 (AZFc)

Fig. 2. Diagrammatic representation of deletions observed in AZF region 
showed presence of any deletion were repeated at least three times with the fresh solutions for re-confirmation. Figure 2 depicts the diagrammatic representation of the deleted AZF regions among the Czech and Indian azoospermics.

The frequencies of various deletions seen in two groups of infertile men are depicted in Table 3. An overall frequency of $2.91 \%$ AZF deletions was observed for Czech infertile men $(n=103)$. The relative frequencies of various deletions were $0.97 \%$ (AZFa), 0\% (AZFb) and 1.94\% (AZFc). If only azoospermic men were considered, then these frequencies were $3.13 \%$ (AZFa), 0\% $(\mathrm{AZFb})$, and $6.26 \%(\mathrm{AZFc})$. Among Indian azoospermics the total frequency of such deletions was $7.69 \%$. The frequency of deletions in $\mathrm{AZFa}$ and $\mathrm{AZFb}$ regions being $0 \%$ and that for AZFc region being $5.13 \%$ and for $\mathrm{AZFa}+\mathrm{b}+\mathrm{c}$ being $2.56 \%$.

The frequency of AZFc mutations was highest $(66.6 \%)$ amongst the cases that showed any AZF deletion, both for the Czech as well as Indian azoospermic males (Table 4). The variations seen between the frequencies of deletions amongst the azoospermic men from Czech Republic and India were statistically insignificant.

\section{TSPY Gene Copy Number}

Four sets of electrophorograms were recorded by the ABI Prism capillary electrophoresis for each patient. These respectively exhibit the
Table 3: Comparison of AZF deletions among Czech and Indian infertile men

\begin{tabular}{lccc}
\hline $\begin{array}{l}\text { Deleted } \\
\text { region }\end{array}$ & $\begin{array}{c}\text { Czech } \\
\text { infertile } \\
\% ; n=103\end{array}$ & $\begin{array}{c}\text { Czech } \\
\text { azoospermic } \\
\% ; n=32\end{array}$ & $\begin{array}{c}\text { Indian } \\
\text { azoospermic } \\
\% ; n=39\end{array}$ \\
\hline AZFa & 0.97 & 3.13 & 0 \\
AZFb & 0 & 0 & 0 \\
AZFc (complete) & 0.97 & 3.13 & 5.13 \\
AZFc (partial) & 0.97 & 3.13 & 0 \\
AZF a+b+c & 0 & 0 & 2.56 \\
\hline Total & 2.91 & 9.38 & 7.69 \\
\hline
\end{tabular}

* No deletion seen in 47 Czech and 30 Indian controls

Table 4: Region-wise distribution of AZF deletions among azoospermic men

\begin{tabular}{llclc}
\hline Region of & \multicolumn{2}{l}{ Czech } & sample & \multicolumn{2}{l}{ Indian } & sample \\
\hline AZF & No. & $\%$ & No. & $\%$ \\
AZFa & $1 / 3$ & 33.3 & $0 / 3$ & - \\
AZFb & $0 / 3$ & - & $0 / 3$ & - \\
AZFc & $2 / 3$ & 66.6 & $2 / 3$ & 66.6 \\
AZF a+b+c & $0 / 3$ & - & $1 / 3$ & 33.3 \\
\hline
\end{tabular}

fluorescent peaks of each gene for 22, 24, 26 and 28 amplification cycles (Fig. 3) with respect to TSPY, AMELY and AMELX. All the data collected were statistically analyzed with respect to various indices, viz., AMELY/AMELX, TSPY/AMELX and TSPY/AMELY. The mean log transformed values of TSPY/AMELY index between the various infertile groups and the controls showed significant increase in TSPY/AMELY ratio in infertile men as compared to the control group (Singh et al. 2005b). Statistical analysis (ANOVA) undertaken on TSPY/AMELY ratios for 22, 24, 26

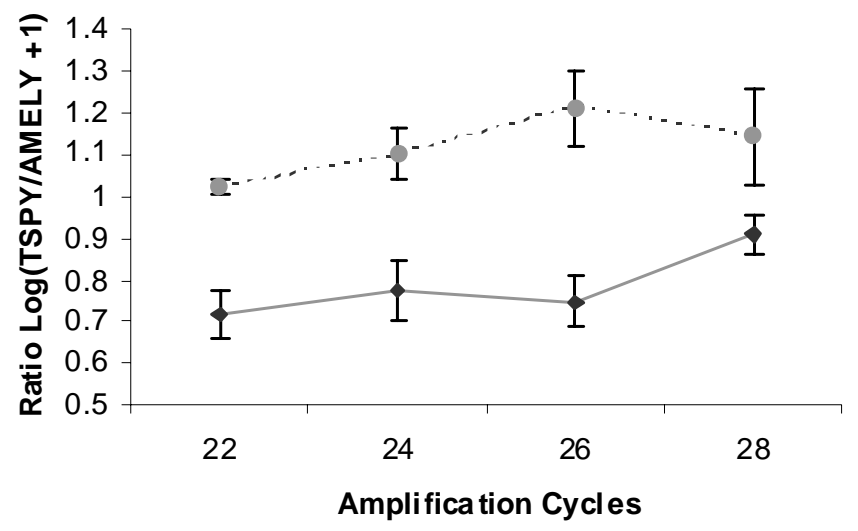

$\downarrow$ Czech Pop ...... Indian Pop

Fig. 3. Comparison of Log transformed values between Czech and Indian azoospermic patients for different amplification cycles 
and 28 cycles with respect to various groups of infertile men and controls had indicated that the f-values for this parameter at all the cycles were non-significant and that the values for 22 cycles were more uniform (Singh et al. 2005b,c).

The comparison of the log transformed values for TSPY/AMELY between the azoospermic groups from Czech Republic and India (Figure 4) revealed that these values differed between the two azoospermic groups at all the amplification cycles viz. 22, 24, 26 and 28. However, these differences were statistically significantly different for 22, 24 and 26 cycles.

\section{DISCUSSION}

\section{AZF Deletions}

AZF deletions have been extensively reported to cause male infertility. In the present study an overall incidence of AZF microdeletions of $2.9 \%$ was observed in Czech infertile men. Similar results have been reported from various populations. Sargin et al. (2004) reported $3.3 \%$ AZF deletions in Turkish infertile men; Katagiri et al. (2004) reported 3.4\% among infertile North American men and a frequency of $4 \%$ was reported by Machatkova et al. (2003) in Czech infertile men while $4.5 \%$ in Croatia by Sertic et al. (2001). However, a wide variation of such microdeletions has been observed in different geographical regions. Kihaile et al. (2005) have reported complete absence $(0 \%)$ of AZF deletions in their sample of azoospermics from Africa, while frequencies of $6.7 \%$ in Brazil (Sao Pedro et al. 2003), 7.1\% in Japan (Carvallo et al. 2003), and $10 \%$ in Romania (Raicu et al. 2003) have been observed. A high frequency of $19.3 \%$ was reported from India by Rao et al. (2004) and even a frequency of $55 \%$ has been reported (Foresta et al. 1998). This large inter-laboratory variation in the frequency of AZF deletions is probably due to the type of patients selected for Ychromosome analysis (Kent-First et al. 1999; McElreavey and Krausz, 1999).

In the present study no deletions were detected amongst oligospermics. Similar observations have been made by several researchers. Calleja Macia et al. (2003) who reported an incidence $13.9 \%$ of AZF deletions in azoospermics, also did not find any deletion in their oligospermic cases. Kihaile et al. (2005) also did not find any AZF deletions among oligospermics. Many researchers have observed that frequencies of AZF deletions are lower among oligospermics as compared to azoospermics (Bor et al. 2002; Kerr et al. 2000).

$9.38 \%$ and $7.69 \%$ AZF micro-deletions were observed amongst Czech and Indian azoospermics, respectively. Corroboratory observations have been made by Madgar et al. (2002) in Israel (8.2\%) and Tse et al. (2002) from Hong Kong and Shanghai (8.2\% and 6\% respectively). However, a low incidence (2.2\%) was reported by Bor et al. (2002) from Denmark and a high incidence (20\%) by Kerr et al. (2000) from New Zealand.

No isolated deletion of AZFa was observed amongst the Indian azoospermic men, while the detection of one AZFa deletion in the Czech group gave a frequency of $0.97 \%$ among infertile men and a frequency of $3.13 \%$ among azoospermics. Concurrent to these, OkutmanEmonts et al. (2004) and Machatkova et al. (2003) also did not find any AZFa deletion among their 71 Turkish and 198 Czech cases, respectively. Least frequencies of AZFa deletions among azoospermic men have been reported among Russians (Loginova et al. 2003), Chinese (Yang et al. 2003), North Americans (Hopps et al. 2003), Indians (Thangaraj et al. 2003) and Japanese (Kihaile et al. 2005).

Micro-deletions in the $\mathrm{AZFa}$ region are thought to be the result of intra-chromosomal homologous recombinations between highly homologous sequences present on both sides of this region. These recombinations occur between two highly homologous human endogenous retrovirus (HERV) sequences (Patience et al. 1997). Such intra-chromosomal recombination between these two HERV sequences can result either in homogenizing sequence conversion or in a micro-deletion in AZFa region.

USP9Y is the candidate gene for AZFa region. The other genes localized in AZFa region that have possible role in spermatogenesis are DBY (Lahn and Page 1997) and UTY (Mazeyrat et al. 1998). DBY is more frequently deleted than USP9Y and its expression is also specific for testes. However, the exact function of these genes still remains unknown (Huynh et al. 2002).

The non-observation of any deletions involving only the $\mathrm{AZFb}$ region in the present study is in pattern with the observations of Machatkova et al. (2003) and Loginova et al. (2003). 
On the other hand, many authors have reported a higher incidence of $\mathrm{AZFb}$ deletions as compared to AZFa deletions (Yang et al. 2003; Hopps et al. 2003).

In accordance to the findings of the present study, wherein a frequency of $1.94 \%$ of AZFc deletions was observed for Czech infertile men and $6.26 \%$ amongst Czech azoospermics, Lynch et al. (2005) have reported an incidence of $2.27 \%$ among Australian infertile men, whereas, Yang et al. (2003) reported an incidence of 12.7\% AZFc deletions among their Chinese patients. $66.6 \%$ AZFc deletions amongst the cases with AZF deletions, as seen for both population groups, is in agreement with the reports of Hopps et al. (2003). However, Thangaraj et al. (2003) reported high incidence of $82.8 \%$. McElreavey et al. (2000) have observed that deletions involving the AZFc region are the most frequent amongst all the $\mathrm{AZF}$ deletions.

Kuroda-Kawaguchi and co-workers (2001) observed that a mechanism similar to the one proposed for $\mathrm{AZFa}$ deletions also exists for $\mathrm{AZFc}$ region. The stretch homology in $\mathrm{AZFc}$ region is bigger $(229 \mathrm{~kb})$ than that of AZFa $(10 \mathrm{~kb})$. Silber and Repping (2002) hypothesized that as the frequency of deletions corresponds to the length of stretch homology, therefore the AZFc deletions are more common.

In the AZFc region, five genes, DAZ, CDY1, BPY2, PRY and TTY2 have been mapped (Vogt et al. 1996; Lahn and Page, 1997) of which DAZ is the candidate gene for AZFc. DAZ encodes for a testes specific protein containing a single RNAbinding motif with 8-24 copies of 24 amino acid sequence, known as 'DAZ repeat' (Reijo et al. 1995; Yen et al. 1997) and at least three functional copies of this gene viz., DAZ1, DAZ2 and DAZ3 have been reported (Saxena et al. 2000).

The partial deletion observed in the AZFc region in one of the Czech azoospermic males probably involves the partial deletion of the candidate gene DAZ. Men with AZFc deletions usually lack all copies of the DAZ gene. However, partial deletions for DAZ have also been reported. de Vries and co-workers (2002) suggested that there may be gene dosage effect e.g., men with 2 deleted DAZ genes may be less affected than those with loss of all DAZ genes. Writzl et al. (2004) have reported a frequency of $2 \%$ deletions of two of four DAZ gene copies in the Slovenian population. Ferlin et al. (2005) reported that only partial AZFc deletions removing DAZ1/DAZ2 seemed to be associated with spermatogenic impairment, whereas those removing DAZ3/ DAZ4 had no or little effect on fertility.

Lynch et al. (2005) have recently described gr/gr sub-deletion of AZFc that removes 2 of 4 copies of DAZ. Lin et al. (2005) have also reported reciprocal duplication product of gr/gr deletion in DAZ gene in the AZFc region. Lapretre et al. (2005) did not find any partial DAZ deletion among fertile men signifying the role of such partial deletions in the causation of infertility.

The combination deletions like AZFa+b, $\mathrm{AZFb}+\mathrm{c}$, or $\mathrm{AZFa}+\mathrm{b}+\mathrm{c}$ are much less frequent than the single region deletions (Hopps et al., 2003). Only one case of $\mathrm{AZFa}+\mathrm{b}+\mathrm{c}$ was observed amongst 39 Indian azoospermic men. The frequency of $\mathrm{AZFa}+\mathrm{b}+\mathrm{c}$ deletions is relatively low in all populations. Kihaile et al. (2005) also observed only one such case among 47 azoospermics from Japan and Africa. El Awady et al. (2004) and Loginova et al. (2003) each reported one such case amongst infertile men studied by them.

Sargin et al. (2004) did not find any case of $\mathrm{AZFa}+\mathrm{b}+\mathrm{c}$ deletion amongst 61 Turkish infertile males. Similar to the present study, wherein no $\mathrm{AZFa}+\mathrm{b}+\mathrm{c}$ deletion was observed in $103 \mathrm{Czech}$ infertile men, Yang et al. (2003) also did not find any such case in 134 azoospermics from China. Amongst 78 men with AZF deletions, Hopps et al. (2003) observed 6 men $(7.7 \%)$ with such deletions. Ferlin et al. (1999) observed that deletions involving more than one AZFcandidate gene are associated with a more severe testicular phenotype.

The wide variation among geographically and ethnically different populations indicates the need of further in depth evaluation, with well defined parameters, of infertile men with respect to micro-deletions involving $\mathrm{AZFa}, \mathrm{AZFb}$, and $\mathrm{AZFc}$ regions of the $\mathrm{Y}$ chromosome. The relative uniformity in the percentages of deletions seen in the present study among geographically and ethnically different populations from Czech Republic and India highlights the importance of following the uniform patient selection criteria.

\section{TSPY Gene}

The present study is probably the first study to ascertain the geographic and ethnic differences associated with TSPY gene copy number in relation to male infertility. 
TSPY gene was selected for evaluation as the function of this gene, which is only expressed in testes, is to integrate TSPY protein into spermatogenesis (Vogel et al. 1997). Its role is specific for the proliferation of germ cells (Schnieders et al. 1996). The homology of TSPY with members of the TTSN gene family that are involved in cell cycle control, also suggest its role in spermatogonial proliferation (Chai et al. 2001; Ozbun et al. 2001).

Single copy genes, AMELY and AMELX were selected for determining various indices like AMELY/AMELX, TSPY/AMELX and TSPY/ AMELY. AMELY lies close to TSPY (Lau, 1999) and like its X-linked homologue AMELX codes for an enamel protein (Lau et al. 1989). To determine the ideal number of cycles at which all the analyzed genes get simultaneously and comparably amplified for quantitative analysis, amplifications were done for 22, 24, 26 and 28 cycles. The values of $22^{\text {nd }}$ cycle indicated more uniformity and sensitivity (Singh et al. 2005b,c). For the quantification of TSPY values, the RQF PCR method of Vodicka et al. (2004) was followed. The results validated the utility of RQF PCR method as statistically analyzable data, with respect to different groups were successfully realized.

Significant differences were observed for TSPY/AMELY values between the azoospermic men from Czech Republic and those from India (Punjab; North West India). Geographical and ethnic variations with respect to various $Y$ chromosomal genes are well known (Santos et al. 2000). Some authors have reported a divergence of up to $10 \%$ in human TSPY (Arnemann et al. 1991; Manz et al. 1993). Schnieders et al. (1996) had also reported the diversity of human TSPY at the transcript level with at least nine different splice variants. These reports coupled with the present observations highlight the need to establish base line data for geographically and ethnically different populations with respect to TSPY copy numbers.

Carlsen et al. (1992) reported that in the past 50 years there has been almost $50 \%$ decline in the sperm concentration. Increase in the TSPY copy numbers over generations might be one factor contributing to such deterioration. The increase in the gene copy number, as observed for TSPY, primarily occurs through gene duplication for which several mechanisms have been reported (Ohno 1970; Lewin 2000). Many authors (Chang et al. 1999; Page et al. 1999; Dada et al. 2004) have observed that AZF microdeletions could result in progressive worsening of sperm production and that with time the oligozoospermic men may become azoospermic. Therefore, the evaluation of TSPY copy numbers and AZF micro-deletions has immense implications for ICSI. These have great value for the understanding of the prognosis and also for better management and counseling of patients with oligospermia or azoospermia.

\section{REFERENCES}

Arnemann J, Jakubiczka S, Thuring S, Schmidtke J 1991. Cloning and sequence analysis of a human Ychromosome-derived, testicular cDNA, TSPY. Genomics. 11: 108-114.

Bor P, Hindkjaer J, Kolvraa S, Ingerslev HJ 2002. Ychromosome microdeletions and cytogenetic findings in unselected ICSI candidates at a Danish fertility clinic. J Assist Reprod Genet, 19: 224231.

Calleja Macias IE, Martinez Garza SG, Gallegos Rivas MC, Ortiz Lopez R, Gomez Guerra L, Barrera Saldana HA, Gutierrez Gutierrez AM 2003. Y chromosome micro-deletion identification in infertile males. Ginecol Obstet Mex, 71: 25-31.

Carlsen E, Giwercman A, Keiding N, Skakkebaek NE 1992. Evidence for decreasing quality of semen during past 50 years. BMJ, 305: 609-613.

Carvalho CM, Fujisawa M, Shirakawa T, Gotoh A, Kamidono S, Freitas Paulo T, Santos SE, Rocha J, Pena SD, Santos FR 2003. Lack of association between $\mathrm{Y}$ chromosome haplogroups and male infertility in Japanese men. Am J Med Genet A, 116: $152-158$.

Chai Z, Sarcevic B, Mawson A, Toh BH 2001. SETrelated cell division autoantigen-1 (CDA1) arrests cell growth. J Biol Chem, 276: 33665-33674.

Chang PL, Sauer MV, Brown S 1999. Y chromosome microdeletion in a father and his four infertile sons. Hum Reprod, 14: 2689-2694.

Conrad C, Hierl T, Glaser B, Taylor K, Zeitler S, Chandley AC, Schempp W 1996. High-resolution fluorescence in situ hybridization of RBM- and TSPYrelated cosmids on released $\mathrm{Y}$ chromatin in humans and pygmy chimpanzees. Chromosome Res, 4: 201206.

Dada R, Gupta NP, Kucheria K 2004. Yq microdeletionsazoospermia factor candidate genes and spermatogenic arrest. J Biomol Tech, 15: 176-183.

de Vries JW, Hoffer MJ, Repping S, Hoovers JM, Leschot NJ, van der Veen F 2002. Reduced copy number of DAZ genes in subfertile and infertile men. Fertil Steril, 77: 68-75.

Dechend F, Williams G, Skawran B, Schubert S, Krawczak M, Tyler-Smith C, Schmidtke J 2000. TSPY variants in six loci on the human Y chromosome. Cytogenet Cell Genet, 91: 67-71.

El Awady MK, El Shater SF, Ragaa E, Atef K, Shaheen IM, Megiud NA 2004. Molecular study on Y 
chromosome microdeletions in Egyptian males with idiopathic infertility. Asian J Androl, 6: 53-57.

Ferlin A, Moro E, Garolla A, Foresta C 1999. Human male infertility and $\mathrm{Y}$ chromosome deletions: role of the AZF-candidate genes DAZ, RBM and DFFRY. Hum Reprod, 14: 1710-1716.

Ferlin A, Tessari A, Ganz F, Marchina E, Barlati S, Garolla A, Engl B, Foresta C 2005. Association of partial $\mathrm{AZFc}$ region deletions with spermatogenic impairment and male infertility. J Med Genet, 42: 209-213.

Foresta C, Ferlin A, Garolla A, Moro E, Pistorello M, Barbaux S, Rossato M 1998. High frequency of well-defined Y-chromosome deletions in idiopathic Sertoli cell-only syndrome. Hum Reprod, 13: 302307.

Hopps CV, Mielnik A, Goldstein M, Palermo GD, Rosenwaks Z, Schlegel PN 2003. Detection of sperm in men with $\mathrm{Y}$ chromosome microdeletions of the $\mathrm{AZFa}, \mathrm{AZFb}$ and AZFc regions. Hum Reprod, 18: 1660-1665.

Huynh T, Mollard R, Trounson A 2002. Selected genetic factors associated with male infertility. Hum Reprod Update, 8: 183-198.

Katagiri Y, Neri QV, Takeuchi T, Schlegel PN, Megid WA, Kent-First M, Rosenwaks Z, Palermo GD 2004. $\mathrm{Y}$ chromosome assessment and its implications for the development of ICSI children. Reprod Biomed Online, 8: 307-318.

Kent-First M, Muallem A, Shultz J, Pryor J, Roberts K, Nolten W, Meisner L, Chandley A, Gouchy G, Jorgensen L, Havighurst T, Grosch J 1999. Defining regions of the Y-chromosome responsible for male infertility and identification of a fourth AZF region (AZFd) by Y-chromosome microdeletion detection. Mol Reprod Dev, 53: 27-41.

Kerr NJ, Zhang J, Sin FY, Benny P, Sin IL 2000. Frequency of microdeletions in the azoospermia factor region of the Y-chromosome of New Zealand men. $N Z$ Med J, 113: 468-470.

Kihaile PE, Yasui A, Shuto Y 2005. Prospective assessment of Y-chromosome microdeletions and reproductive outcomes among infertile couples of Japanese and African origin. J Exp Clin Assist Reprod, 29: $2-9$.

Kuroda-Kawaguchi T, Skaletsky H, Brown LG, Minx PJ, Cordum HS, Waterston RH, Wilson RK, Silber S, Oates R, Rozen S, Page DC 2001. The AZFc region of the $\mathrm{Y}$ chromosome features massive palindromes and uniform recurrent deletions in infertile men. Nat Genet, 29: 279-286.

Lahn BT, Page DC 1997. Functional coherence of human Y chromosome. Science, 278: 675-680.

Lau YF 1999. Gonadoblastoma, testicular and prostate cancers, and the TSPY gene. Am J Hum Genet, 64: 921-927.

Lau EC, Mohandas TK, Shapiro LJ, Slavkin HC, Snead ML 1989. Human and mouse amelogenin gene loci are on the sex chromosomes. Genomics, 4: 162168.

Lepretre AC, Patrat C, Mitchell M, Jouannet P, Bienvenu T 2005. No partial DAZ deletions but frequent gene conversion events on the Y chromosome of fertile men. J Assist Reprod Genet, 22: 141-148.

Lewin B 2000. Gene VII. New York: Oxford University
Press.

Lin YW, Thi DA, Kuo PL, Hsu CC, Huang BD, Yu YH, Vogt PH, Krause W, Ferlin A, Foresta C, Bienvenu T, Schempp W, Yen PH 2005. Polymorphisms associated with the DAZ genes on the human Y chromosome. Genomics, 86: 431-438.

Loginova IuA, Nagornaia II, Shlykova SA, Petrova LI, Rybakova MV, Kuznetsova TV, Baranov VS 2003. Molecular genetic analysis of Y-chromosome micro deletions in men with severe spermatogenic defects. Mol Biol (Mosk), 37: 74-80.

Lynch M, Cram DS, Reilly A, O’Bryan MK, Baker HW, de Kretser DM, McLachlan RI 2005. The Y chromosome $\mathrm{gr} / \mathrm{gr}$ subdeletion is associated with male infertility. Mol Hum Reprod, 11: 507-512.

Machatkova M, Krebsova A, Smetanova I, Matejckova M, Vilimova S, Sobek A, Macek M Sr 2003. Chromosome Y microdeletions in Czech men with severe reproductive disorders. Cas Lek Cesk, 142: 670-675.

Madgar I, Green L, Kent-First M, Weissenberg R, Gershoni-Baruch R, Goldman B, Friedman E 2002. Genotyping of Israeli infertile men with idiopathic oligozoospermia. Clin Genet, 62: 203-207.

Manz E, Schnieders F, Brechlin AM, Schmidtke J 1993. TSPY-related sequences represent a microheterogeneous gene family organized as constitutive elements in DYZ5 tandem repeat units on the human Y chromosome. Genomics, 17: 726731.

Mazeyrat S, Saut N, Sargent CA, Grimmond S, Longepied G, Ehrmann IE, Ellis PS, Greenfield A, Affara NA, Mitchell MJ 1998. The mouse Y chromosome interval necessary for spermatogonial proliferation is gene dense with syntenic homology to the human AZFa region. Hum Mol Genet, 7: 1713-1724.

McElreavey K, Krausz C 1999. Sex Chromosome Genetics 99. Male infertility and the Y chromosome. Am J Hum Genet, 64: 928-933.

Meschede D, Lemke B, Behre HM, DeGyter C Nieschlag E, Horst J 2000. Clustering of male infertility in families of couples treated with intracytoplasmic sperm injection. Hum Reprod, 15: 1604-1608.

Miller SA, Dykes DD, Polesky HF 1998. A simple salting out procedure for extracting DNA from human nucleated cells. Nucl Acids Res, 16: 1215-1216.

Ohno S 1970. Evolution by Gene Duplication. Berlin: Springer Verlag.

Okutman-Emonts O, Pehlivan S, Tavmergen E, Tavmergen-Goker EN, Ozkinay F 2004. Screening of Y chromosome microdeletion which contains AZF regions in 71 Turkish azoospermic men. Genet Couns, 15: 199-205.

Ozbun LL, You L, Kiang S, Angdisen J, Martinez A, Jakowlew SB 2001. Identification of differentially expressed nucleolar TGF-beta1 target (DENTT) in human lung cancer cells that is a new member of the TSPY/SET/NAP-1 superfamily. Genomics, 73: 179-193.

Page DC, Silber S, Brown LG 1999. Men with infertility caused by AZFc deletion can produce sons by intracytoplasmic sperm injection, but are likely to transmit the deletion and infertility. Hum Reprod, 14,:1722-1726

Patience C, Wilkinson DA, Weiss RA 1997. Our retroviral 
heritage. Trends Genet, 13: 116-120.

Raicu F, Popa L, Apostol P, Cimponeriu D, Dan L, Ilinca E, Dracea LL, Marinescu B, Gavrila L 2003. Screening for microdeletions in human $\mathrm{Y}$ chromosome-AZF candidate genes and male infertility. J Cell Mol Med,7: 43-48.

Rao L, Babu A, Kanakavalli M, Padmalatha V, Singh A, Singh PK, Deenadayal M, Singh L 2004. Chromosomal abnormalities and y chromosome microdeletions in infertile men with varicocele and idiopathic infertility of South Indian origin. J Androl, 25: $147-153$.

Reijo R, Lee TY, Salo P, Alagappan R, Brown LG, Rosenberg M, Rozen S, Jaffe T, Straus D, Hovatta O, de la Chapelle A, Silber S, Page DC 1995. Diverse spermatogenic defects in humans caused by $\mathrm{Y}$ chromosome deletions encompassing a novel RNAbinding protein gene. Nature Genet, 10: 383-393.

Santos FR, Pandya A, Kayser M, Mitchell RJ, Liu A, Singh L, Destro-Bisol G, Novelletto A, Qamar R, Mehdi SQ, Adhikari R, de Knijff P, Tyler-Smith C 2000. A polymorphic L1 retroposon insertion in the centromere of the human Y chromosome. Hum Mol Genet, 9: 421-430.

SaoPedro SL, Fraietta R, Spaine D, Porto CS, Srougi M, Cedenho AP, Avellar MC 2003. Prevalence of Y chromosome deletions in a Brazilian population of nonobstructive azoospermic and severely oligozoospermic men. Braz J Med Biol Res, 36: 787-793.

Sargin CF, Berker-Karauzum S, Manguoglu E, Erdogru T, Karaveli S, Gulkesen KH, Baykara M, Luleci G 2004. AZF microdeletions on the $\mathrm{Y}$ chromosome of infertile men from Turkey. Ann Genet, 47: 61-68.

Saxena R, de Vries JW, Repping S, Alagappan RK, Skaletsky H, Brown LG, Ma P, Chen E, Hoovers JM, Page DC 2000. Four DAZ genes in two clusters found in the AZFc region of the human $Y$ chromosome. Genomics, 67: 256-267

Schnieders F, Dork T, Arnemann J, Vogel T, Werner M, Schmidtke J 1996. Testis-specific protein, Yencoded (TSPY) expression in testicular tissues. Hum Mol Genet, 5: 1801-1807.

Sertic J, Cvitkovic P, Myers A, Saiki RK, Stavljenic Rukavina A 2001. Genetic markers of male infertility: Y chromosome microdeletions and cystic fibrosis transmembrane conductance gene mutations. Croat Med J, 42: 416-420.

Silber SJ, Repping S 2002. Transmission of male infertility to future generations: lessons from the Y chromosome. Hum Reprod Update, 8: 217-229.

Singh AR 2005. Y Chromosome Micro-deletions and TSPY Gene Copy Numbers: A Comparative Study of Czech and Indian Infertile Men. Ph.D. Thesis. Palacky University, Olomouc, Czech Republic.
Singh AR, Vrtel R, Vodicka R, Dhaifalah I, Konvalinka D, Janikova M, Santavy J 2005a. Y chromosome and Male Infertility. Int J Hum Genet, 5(4): 225235 .

Singh AR, Vrtel R, Vodicka R, Dusek L, Krejcirikova E, Vrbicka D, Santavy J, Santava A. 2005b. Quantification of TSPY gene repetitions and AZF screening in infertile men. XVI Izakovièov Memorial Genetics Conference, Slovakia.

Singh AR, Vodicka R, Vrtel R, Svabova D, Santava A, Santavy J 2005c. Quantification of TSPY gene and probable identification of gonosomal aberrations in infertile men using capillary electrophoresis. European Congress of Human Genetics, Prague, Czech Republic.

Thangaraj K, Gupta NJ, Pavani K, Reddy AG, Subramainan S, Rani DS, Ghosh B, Chakravarty B, Singh L 2003. Y chromosome deletions in azoospermic men in India. J Androl, 24: 588-597.

Tse JY, Yeung WS, Ng EH, Cheng LN, Zhu HB, Teng XM, Liu YK, Ho PC 2002. A comparative study of $\mathrm{Y}$ chromosome microdeletions in infertile males from two Chinese populations. J Assist Reprod Genet, 19: 376-383.

Vodicka R, Vrtel R, Scheinost O, Zapletalova J, Dusek L, Geierova M, Santavy J 2004. Refined quantitative fluorescent PCR of Y-chromosome DNA sequences mosaics in Turner's syndrome patients- alternative to real-time PCR. J Biochem Biophys Methods, 60: $151-162$.

Vogel T, Dechend F, Manz E, Jung C, Jakubiczka S, Fehr S, Schmidtke J, Schnieders F 1997. Organization and expression of bovine TSPY. Mamm Genome, 8: $491-496$

Vogt PH, Edelmann A, Kirsch S, Henegariu O, Hirschmann P, Kiesewetter F, Kohn FM, Schill WB, Farah S, Ramos C, Hartmann M, Hartschuh W, Meschede D, Behre HM, Castel A, Nieschlag E, Weidner W, Grone HJ, Jung A, Engel W, Haidl G 1996. Human Y chromosome azoospermia factors (AZF) mapped to different subregions in Yq11. Hum Mol Genet, 5: 933-943.

Writzl K, Sehic A, Terzic R, Peterlin B 2004. Copy number of DAZ genes in Slovenian and Bosnian general population. Coll Antropol, 28: 283-289.

Yang Y, Zhang SZ, Peng LM, Ding XP, Lin L, Wang J 2003, Studies on molecular epidemiology of Y chromosome azoospermia factor microdeletions in Chinese patients with idiopathic azoospermia or severe oligozoospermia. Zhonghua Yi Хие Yi Chuan Xue Za Zhi, 20: 385-389.

Yen PH, Chai NN, Salido EC 1997. The human DAZ genes, a putative male infertility factor on the $Y$ chromosome, are highly polymorphic in the DAZ repeat regions. Mamm Genome, 8: 756-759. 